\title{
LIETUVOS NUOSTOLIAI 1812 M. KARE
}

\author{
Dr. Virgilijus PUGAČIAUSKAS \\ Lietuvos karo akademija, Lietuvos istorijos institutas
}

\section{Ivadas}

1812 m. Prancūzijai ir Rusijai, dviem karinėms galybėms Europoje, nusprendus išsiaiškinti tarpusavio prieštaravimus karinès jẻgos priemonėmis, Lietuva pusę metų buvo įtraukta į karinių veiksmų zoną. Napoleoną ir Didžiają Armiją Lietuvos gyventojai sutiko palankiai, vertindami juos kaip išvaduotojus iš Rusijos imperijos, o Lietuvos laikinosios valdžios sukūrimas padidino prancūzų šalininkų gretas bei dar labiau sustiprino valstybingumo atkūrimą. Lietuva, kaip ir tikèjosi prancūzų imperatorius, tapo sajungininke, kuri turèjo visų pirma pasirūpinti toli į Rusijos gilumą nužygiavusios Didžiosios Armijos gyvybiniais poreikiais - maistu ir pašarais, taip pat tikètasi konkrečios karinès paramos. Lietuvos laikinoji valdžia savo pastangas sutelkè į žmogiškujų resursų mobilizaciją ir stengèsi efektyviai išnaudoti neturtingo krašto ūkinį potencialą, kad galètų sėkmingai igyvendinti iškeltus uždavinius. Pasistengti derèjo, juolab kad tautos sugebejjimą susitelkti ir spręsti iškilusius iššūkius Napoleonas vertino kaip subrendusios valstybingumui tautos vieną iš svarbiausių bruožų. Tokią politikos aksiomą arba požiūrį i buvusios valstybès atkūrimą jis išdèstẻ Vilniuje susirinkusiems Lietuvos ir Lenkijos politikams.

Per visą karo laikotarpi Lietuva užèmè itin svarbią strateginę poziciją Napoleono karinejje politikoje: čia buvo ikurta svarbiausia užnugario karinè bazé, iš kurios nusitiesė Didžiajai Armijai gyvybiškai svarbi komunikacinẻ arterija. Galima sakyti, kad Lietuvos gyventojai pajuto karo, o, tiksliau sakant, visus su karo veiksmais susijusius sunkumus.

Straipsnyje nagrinėjami Lietuvos gyventojų prancūzmečiu patirti nuostoliai dèl Didžiosos Armijos savivalès, maisto, pašaro ir transporto rekvizicijų, išaugusios mokesčių naštos, karinių abiejų priešininkų susidūrimų, taip pat dėmesys sutelkiamas į civilių gyventojų aukas bei siekiama nustatyti Lietuvos reguliariosios iš karo nuostolių įvertinimo komisijos vadinamosios „Generalinès lentelès“ apie gyventojų patirtus nuostolius dèl $1812 \mathrm{~m}$. Rusijos kariuomenès ir Didžiosios Armijos neteisètai įvykdytų rekvizicijų ir kitokių savivaliavimo veiksmų sužinome, kad Vilniaus gubernijos nuostoliai sudarè - 12815790 rb. sidabru, o 
Gardino gubernijos - $8141261 \mathrm{rb}$. sidabru1. Nuostolių suma gerokai išaugo suskaičiavus oficialių rekvizicijų finansinę išraišką, o, tiksliau sakant, Vilniaus gubernijai skaičiuojama 19 273, 007 rb sidabru, atitinkamai Gardino - 32 535, 616 rb. sidabru, Minsko - 34, 186.976 rb. sidabru, Baltstogès - 777.321 rb. sidabru² $^{2}$ Kokie pagrindiniai veiksniai nulèmé Lietuvos gyventojų patirtus didžiulius materialinius nuostolius?

\section{Didžiosios Armijos savivalės pasekmės}

Karo pradžioje Lietuvos teritorijoje nevyko didesnių priešininkų susidūrimų netgi stambiausi miestai - gubernijų centrai, gynybiniu požiūriu svarbūs objektai - buvo atiduoti be mūšio. Tegalime paminèti vos kelis priešininkų didesnius susidūrimų ties Miru ir Kobrinu bei daugybę epizodinių ariergardų susidūrimu, pavyzdžiui, Vilniaus departamente vienintelis susidūrimas vyko ties Ukmerge. Taigi gyventojai nepatyré didesnių nuostoliu, išskyrus Kobrino miestiečius, kai sudege 548 namai. Kita vertus, Rusijos kariuomenè, skubiai atsitraukdama, pirmiausia stengèsi sunaikinti karinės paskirties objektus: maisto ir pašaro, amuncijos sandèlius bei tiltus per upes ${ }^{3}$. Todèl Lietuvos gyventojų patirtus pirmuosius didelius nuostolius dera sieti su Didžiosios Armijos veiksmais, kadangi pirmosiomis karo dienomis susikloste komplikuota situacija, kai dèl spartaus žygiavimo ji atitrūko nuo maisto gurguolių ir didžiulès karinės pajègos (per 400000 kariu) buvo priverstos pačios apsirūpinti maisto produktais ir pašaru arkliams. Pirmoji maisto gurguole pasiekė Kauną tik liepos $8 \mathrm{~d}^{4}$

Didžiausius nuostolius patyrè Vilniaus gubernija, kadangi per josios teri-

\footnotetext{
${ }^{1}$ Karo nuostolių įvertinimo komisija, veikusi 181303 02-1816 1223 laikotarpiu, registravo Vilniaus, Minsko, Gardino ir Baltstogès gubernijų, t. y. Lietuvos laikinosios vyriausybès komisijai 4 pavaldžių departamentų, gyventojų patirtus nuostolius: sudeginti ir sugriauti dūmai bei ịvairios paskirties pastatai, sunaikinti pasèliai, pagrobti naminiai gyvuliai ir judamas turtas, taip pat nugaišę nuo ligų gyvuliai. Komisija atskirai surinko duomenis apie Rusijos kariuomenès vykdytas rekvizicijas ir savivaliavimus. Генеральная табель No. 318, 319, Виленский Временик (Акты и документы архива Виленского, Ковенского и Гроднеского Генерал-Губернаторского управления, относяшеюся к истории 1812-1813 г. г.), кн. 5, ч. 2, Вильна, 1913, с. 275; Iwaszkiewicz J. Rejestracja i indemnizacja strat wojenych na Litwie po roku 1812, Likwidacja skutków wojny w dziedzinie stosunków prawnych i ekonomicznych w Polsce, Warszawa, 1917, s. 132-146.

2 Iwaszkiewicz J., Litwa w roku 1812, Kraków, 1912, s. 321;

3 Орловский Е., Гродненская старина, ч. 1, Гродна, 1910, с. 23; Хрептович - Бутенев К., Заметка о военных действиях в 1812 году в местностях Новогруцкого и Ошмянского уездов, Санкт - Петербург, 1911, с. 14; Dundulis B. Lietuva Napoleono agresijos metais (1807-1812), Vilnius, 1981, p. 64; Бескровный Л. Г. Отечественная война 1812 года, Москва, 1962, с. 277, 281, 283.

${ }^{4}$ Kukiel M., Wojna 1812 roku, Kraków, 1937, t. 1, s. 363.
} 
toriją pirmosiomis karo dienomis žygiavo pagrindinė Napoleono vadovaujama armija (apie 220 tūkst. kariu). Labiausiai nukentejo vietovès prie pagrindiniu traktų, esančiu Kauno, Vilniaus, Trakų, Užnerio (Švenčioniu) apskrityse. Kariniai daliniai masiškai vykde savavališkas rekvizicijas: nuganydavo ir ištrypdavo pasèlius, paimdavo iš gyventojų maisto produktus, grūdus, naminius gyvulius, o gyvenamuosius namus nusiaubdavo, šie veiksmai dažniausiai peraugdavo i atvirą plěšikavimą, dvaro ir valstiečiu trobesių padeginejimus, taip pat pasitaikydavo atvejų, kai gyventojai buvo tiesiog sušaudomi. Napoleono gvardija apiplěšè Kauną ir jo apylinkes, o Rumšiškès, Žiežmariai, Vievis ir kitos vietovès prie Kauno-Vilniaus kelio buvo beveik visiškai sudegintos ir sugriautos. Karo pradžioje Vilniaus gubernijoje mažiausiai nukentėjo tik Žemaitija, kadangi 10-ojo korpuso vadas maršalas Etienas Makdonaldas sugebejjo užtikrinti deramą tvarką daliniuose ir juos aprūpinti maistu ir pašaru, gyventojams buvo išduodami atitinkami dokumentai - „bonai“, liudijantys rekvizicijos faktą bei rekvizuotu priemonių kieki ${ }^{5}$.

Tokie veiksmai pirmosiomis karo dienomis liudijo apie sparčiai įsivyraujančias dezorganizacijos ir demoralizacijos tendencijas Napoleono vadovaujamos armijos gretose ir darè neigiamą ittaką itin palankiai nusiteikusiems vietiniams gyventojams, kurie, baimindamiesi dèl savo gyvybès ir turto, buvo priversti slėptis miškuose. Kiekvienai gausiai kariuomenei, taip pat ir Didžiajai Armijai, apsirūpinimas maisto produktais karo metu sukeldavo daugybę problemų, kurias pagal iprastinę praktiką ji spręsdavo pasinaudodama užimto krašto ištekliais ${ }^{6}$. Tačiau šiuo atveju, kaip prisimena tų ivykių amžininkas Faberas du Fauras, dailininkas, kurio uždavinys piešti karo vaizdus žygio metu, „reikalingo maisto parūpinimas iš krašto, pro kuri žygiuojama, jokiame karo žygyje nebuvo toks dažnas ir niekuomet nebuvo palydimas tokių sunkinančių aplinkybių tiek kariams, tiek ir krašto gyventojams, kaip šiame kare" ${ }^{\text {"7 }}$. Kita vertus, nederètų užmiršti ir kitos priežasties, sąlygojusios tokius kariu savivaliavimus: Lietuva jiems buvo kraštas, kuriame reikejjo susikauti su priešu. Netgi ir Napoleonas Vilkaviškyje paskelbtame kreipimesi i armiją painiojosi: skelbẻ antrojo karo dẻl Lenkijos

\footnotetext{
${ }^{5}$ Dundulis B., Napoleón et la Lituanie en 1812, Paris, 1941, p. 115, 117-118; Dundulis B. Lietuva Napoleono agresijos metais, p. 59, 111.

${ }^{6}$ Bielecki R. Wielka Armia, Warszawa, 1995, p. 359-360.

${ }^{7}$ Dailininkas nupiešè Lietuvos valstiečio apiplěšimo sceną Vilniaus apylinkèse. $1812 \mathrm{~m}$. birželio 29 d. Christian Wilhem von Faber du Faur ir jo 1812 metų karo veiksmų Lietuvoje vaizdai. Reklaitis P. Prarastosios Lietuvos pėdsakų beieškant, Vilnius, 1999, p. 298-299, 304.
} 
pradžią ir čia pat teritoriją anapus Nemuno vadino priešo kraštu ${ }^{8}$.

Taigi dèl tokio elgesio karo pradžioje Lietuvos gyventojams tapo nebeaišku, kaip atskirti rekviziciją nuo plèšimo ir prievartos, kadangi ribos tarp šiu veiksmų buvo visiškai išsitrynusios. Tokie karinių dalinių priešiški veiksmai prieš vietinius gyventojus, anot istoriko Danielius Beavua, parodantys „, dvigubą ,išvaduotojo“ veidą“, tebesitęsè, kadangi paskui pagrindines jègas trauké kiti daliniai, kurie žygiuodami tais pačiais traktais ieškojo maisto ir pašaro pas jau apiplěštus gyventojus 9 .

Tokią išvadą patvirtina Lietuvos laikinosios valdžios instituciju dokumentacija. Vilniaus departamento Trakų apskrities paprefektis Juozapas Petrikovskis nuolatos gaudavo pranešimų apie apiplèštas ir sudegintas gyvenvietes, neteisètas rekvizijas ir kitokius pražygiuojančių dalinių nusižengimus. Ašmenos apskrities vadovas Ignas Žaba pirmuosius įspūdžius, patirtus pražygiavus Didžiajai Armijai, rašte Lietuvos laikinajai vyriausybès komisijai (toliau - LLVK) aprašè tokiais žodžiais: „Tą metą lydèjo įvykiai, kuriuos sunku netgi aprašyti ir ịsivaizduoti“"10. Apie analogiškas situacijas savo pranešimuose Laikinajai vyriausybei raportavo Užnerio (Švenčioniu) ir Ukmergès apskričių vadovai ${ }^{11}$. Kaip rodo šaltinai, tuo metu gyventojų saugumo nepavyko užtikrinti netgi artimiausiose Vilniaus apylinkėse, štai tik keletas konkrečių faktų: visiškai nusiaubtas Verkių dvaras, be to, sudeginta dalis valstiečių namų, Fabijoniškių kaime nušautas ūkininko sūnus, laisvai šeimininkauta Trinapolio vienuolyne, apiplèštas bajoro Juozapo Eismonto namas Markučiuose (savininkas nuostolius ivertino $4000 \mathrm{rb}$. sidabru), taip pat nušienauti dvaro ir valstiečių pasèliai. Tiesą pasakius, kai kuriems atkakliausiems, pasiskundus armijos vadovybei, pavyko gauti vienkartines kompenscijas, tačiau tokių būta vos vienas kitas ${ }^{12}$.

Gardino departamentui, pro kurio teritoriją žygiavo Vestfalijos karaliaus Že-

\footnotetext{
${ }^{8}$ Pugačiauskas V. Napoleono administracija Lietuvoje, Vilnius, 1998, p. 38-39.

${ }^{9}$ Beauvois D. Les franēais ą Vilna en 1812. L'epoque Napoléoniene et les slaves, Prace Slawistyczne, Wrocław, 1982, t. 24, s. 64.

${ }^{10}$ Trakų apskrities paprefekčio J. Petrikovskio 18120725 raštas LLVK, Lietuvos valstybès istorijos archyvas (toliau - LVIA), f. 1532, ap. 1, b. 7, 1. 112-113; Ašmenos apskrities parprefekčio 18120710 raštas LLVK. Ten pat, 1. 287.

${ }^{11}$ Užnerio ir Ukmergès apskričių paprefekčių 181206 raštai LLVK. Ten pat, 1. 103, 148, 168.

${ }^{12}$ Pavyzdžiui, už sudegintą lūšnelę savininkui sumokèta 100 frankų. Письмо Виленского помещика Эйсмонта о пребывании Наполеона в Вильне в 1812 году, Военский К. Акты, документы и материалы для политической и бытовой истории 1812 года, Санкт-Петербург, 1909, Т. 1, c. 416-417; Vilniaus apskrities gyventojų raštai 181207 08, 16 raštai, LVIA, f. 1532, ap. 1, b. 7, 1. 25, 27-30,33.
} 
romo vadovaujami daliniai, galima sakyti, pasisekè labiau, smarkiai nukentėjo tik kai kuriu vietoviu gyventojai, pavyzdžiui, Berštu kaimą apiplèše iš Merkinės atvykęs prancūzų dalinys, o liepos 24 d. Lydos apskritį nusiaubẻ generolo Dominyko Vandamo vadovaujamas dalinys. Tačiau bene daugiausia nuostolių patyre Ščiučino gyventojai, netikètai užpulti vestfaliečių dalinio (3 nušauti, 2 sužeisti, kelios dešimtys sumuštų, o namai apiplěšti). Tokių lokalių savivalès pavyzdžių, turimais duomenimis, dargi fiksuojame Gardino ir Naugarduko apskrityse, tačiau šis reiškinys neigavo tokio masinio pobūdžio kaip minètose Vilniaus departamento apskrityse. Tokị nuosaikesnį dalinių elgesi galima paaiškinti elementaria priežastimi: per Gardino departamentą pražygiavo vos 80 tūkst. karių, o štai Vilniaus - tris kartus daugiau. Kita vertus, apie trečdali šių pajègų sudare 5-asis korpusas, suformuotas tik iš lenkų kariu, vadovaujamų kunigaikščio Jozefo Poniatovskio ${ }^{13}$.

Minsko departamente pirmosiomis karo savaitėmis Didžiosios Armijos dalinių savivaliavimo mastai taip pat nepasiekè tokio masinio pobūdžio kaip Vilniaus departamente. Tai sąlygojo keletas palankių aplinkybių. 1-ojo korpuso vadas maršalas Nikolia Davu, atsiskyręs nuo pagrindinių pajègu ir užėmęs Minską, liepos 8 d. sugebejjo priversti pavaldinius griežtai laikytis karinės drausmès, o nepaklusnius baudè griežtomis priemonėmis: 13 karių, pagautų grobiant prekes vienoje iš Minsko parduotuvių, buvo viešai sušaudyti. Kita vertus, Davu viešuose kreipimuose i savo pavaldinius priminè, kad jie užėmè ne priešų, bet sajungininkų kraštą. Tokia vadovybès griežta ir aiški pozicija drausmino eilinius karius. Ne mažiau svarbu ir tai, kad Minske Davu lengvai sprendẻ dalinių maisto aprūpinimo problemą, kadangi galèjo pasinaudoti rusų kariuomenès sandèliuose paliktomis maisto ir pašaro atsargomis (duonos pakako 5 dienoms) bei pasinaudoti jų paliktomis kepyklomis. Paskubomis besitraukiantys rusų daliniai nesugebejjo jų sunaikinti, kaip tai atsitiko Vilniuje ${ }^{14}$. Tiesa, kur kas labiau nukentèjo Vileikos, Disnos, Borisovo apskritys, nes pro tas Didžiosios Armijos pagrindinès pajègos žygiavo iš Vilniaus i Vitebską ir Smolenską ${ }^{15}$. Iš keturių departamentų,

\footnotetext{
${ }^{13}$ Историческая записка о событиях в Гроднеской губернии в 1812 году, Военский К. Min., veik, p. 442.

14 Цяплова В. А, Каханоскі А. Г, Грыбко І. Л, Гісторыя Беларусі ХІХ ст., Мінцк, 2004, с. 46; Краснянский В. Г. Минский департемент Великого Княжества Литовского (эпизод из истории войны 1812 г., Санкт-Петербург, 1902, с. 6, 23; Iwaszkiewicz J. Litwa w roku 1812, s. 87-88. 15 Записка Минского Губернатора от 31 мая 1838 г. о состоянии губернии в 1812 году, Военский K. Min., veik, p. 461-462; О беглых француских солдат, Акты, издаваемые Виленскою комиссиею для разбора древних актов. Документы и материалы, относящиеся к истории Отечественной войны 1812 г. Вильна, 1912, Т. 37, с. 232; О грабежах в окресностяхь г. Докшиць французкими войсками. Ten pat, c. 224 - 225; Об ограблении помещиков и крестянь Березинского кантона итальянскими войсками. Ten pat, c. 213-232.
} 
pavaldžių LLVK, mažiausiai nuostolių patyrè Baltstogès departamentas, išsidèstęs gerokai atokiau nuo karinių veiksmų zonos

Platus nukentejusių vietovių sąrašas liudija masinį Didžiosios Armijos dalinių savivaliavimą bei pirmuosius didžiulius materialinius nuostolius, patirtus vietinių gyventojų. Tačiau didžiausias skriaudas gyventojai patyrẻ dẻl marodierių, dezertyrų ir tiesiog dèl ịvairiausių priežasčių nuo savo dalinių atsilikusių karių kriminalinio elgesio. Šis reiškinys liepos mèn. igavo visuotini nekontroliuojamą pobūdị, be to, būtent jiems galima drąsiai priskirti kaltę dèl civilių gyventojų žudymo, todèl tikslinga tai aptarti išsamiai. Jau pirmosiomis Napoleono armijos buvimo Lietuvoje, išskyrus Žemaitiją, dienomis civilių gyventojų saugumui kilo realus pavojus dèl pavienių ir susijungusių $\mathfrak{i}$ būrius dezertyrų bei marodierių užpuolimu, kai buvo atvirai žudomi žmonès, plešsiamas dvarininkų ir valstiečių turtas, deginami namai, atimami gyvuliai ir t. t. Didžiausią mastą tokia kriminalinė veikla igavo Trakų apskrityje, kur liepos mèn viduryje, anot paprefekčio Juozapo Petrikovskio, galèjo būti iki 1000 atsilikusių karių, apsijungusių i ivvairaus dydžio gaujas ir nuolatos terorizijuojančiu gyventojus: sudeginta keletas dvarų, keliolika kaimų ir smukliu, nužydyta dešimtys žmonių ${ }^{16}$.

Liepos 14-22 d. Trakų apskrityje buvo areštuota 90 Didžiosios Armijos marodierių, dezertyrų ir atsilikèlių. Suimtujų sarašas, kuriame nurodyti pagrindiniai duomenys (vardas, pavarde, kariuomenès rūšis, pulko ir būrio numeris bei trumpai aprašytos suėmimo aplinkybès) suteikia nemažai papildomos informacijos. Paiaškèjo, kad nedisciplinuotumu pasižymėjo ịvairių Didžiosios Armijos dalinių kariai, tačiau daugausia suimtujų sudare italų kariai, ypač generolo Dominyko Pino vadovaujamos divizijos, kurie nedidelèmis grupelèmis, niekieno netrukdomi, sugebėdavo klajoti po apskritị dvi tris savaites. Dalis iš jų netgi neturèjo nei ginklų (iš 78 suimtų tik 20 turẻjo šaunamaji ginklą), nei amunicijos ir netgi apsirengę skarmalais bei basi. Didžiają daugumą sudarẻ marodieriai, sugauti ịvykio vietoje, dažniausiai vietinių gyventojų pastangomis, arba lenkų generolo Vincento Krasinskio gvardijos kariai, nors Trakuose ir apskrityje tvarką turèjo prižiūrèti karinio komendanto Veberio vadovaujamas būrys ${ }^{17}$.

Ypatingai plačai marodieriai veikè Ašmenos apskrityje, kur ištisą liepos

\footnotetext{
${ }^{16}$ Dundulis B. Napoléon et la Lituanie en 1812, Paris, 1941, p. 117; Trakų apskrities paprefekčio 1812 0714 raštas LLVK, LVIA, f. 1532, ap. 1, b. 7, 1. 261.

${ }^{17}$ Napoleonas siekdamas atstatyti drausmę karių gretose ir pažaboti marodierių siautejimą Lietuvos miestuose ịkūrè judriąsias kolonas ir karo teismų komisijas. Dundulis B. Lietuva napoleono agresijos metais, p. 112; Marodierių ir atsilikèlių, suimtų Trakų apskrityje 18120614 - 22 sąrašai. LVIA, f1532, ap1, b. 7, 1. 109-110, 261-264.
} 
mėnesi siaubė dvarus, pasitaikydavo atvejų, kad žude bajorus ir valstiečius, kurie negalèjo deramai pasipriešinti šaunamaisiais ginklais apsiginklavusiems savivaliautojams. Apskrities gyventojų pastangos pasipriešinti neteisėtiems karių veiksmams kartais duodavo netikètų rezultatų: vietinès valdžios areštuotus 27 marodierius, pagautus plèšimo metu, pražygiuojanti karinè komanda išlaisvino ir netgi leido susidoroti su juos sulaikusiais asmenimis ${ }^{18}$. Tiesa, derètų dar pridurti, kad kai kurie apskrities gyventojai pasistengè pasinaudoti tokia nestabilia situacija, pavyzdžiui, Daniušavos palivarke gyvenantis bajoras Jonas Narkevičius su savo ekonomu Juozapu Falkovskiu ir dar keletu bajorų priglaude ginkluotu marodieriu gaują ir kartu su ja užpuldinejjo Brindiškių, Gruodžių palivarkus ${ }^{19}$.

Napoleono armijos „kriminalinių veiksmų“ zona apėmè prie pagrindinių link Rusijos vedančiu traktų esančias Vilniaus, Užnerio ir Ukmergès apskritis ${ }^{20}$. Analogiška situacija susiformavo Gardino departamente, Lydos apskrityje, kurios miškingose vietovèse gyventojus persekiojo marodierių, susibūrusių po 4-20 žmonių, gaujos ${ }^{21}$. Minsko departamente labiausiai nuo marodierių siautèjimo nukentejjo Borisovo apskritis, per kurios teritoriją vyko intensyvus kariniu daliniu judejjimas traktu i Smolenską. Tik rugpjūčio $12 \mathrm{~d}$. Minsko departamento gubernatorius generolas Mikalojus Bronikovskis laikraštyje Tymczasowa gazeta Minska pranešè apie pasibaigusią kovą su marodieriais ${ }^{22}$. Kalbėdami apie marodierių ir dezertyrų i̇vykdytas civiliu gyventojų žudynes, deja, negalime operuoti tiksliais skaičiais, tačiau, remiantis turimais šaltiniais, galima teigti, kad galejjo būti nužudyta apie du šimtus žmonių.

Reikia pabrèžti, kad Didžiosios Armijos savivaliavimu problema išliko aktuali per visą karo laikotarpi, kadangi per LLVK pavaldžią teritoriją nusidriekė pagrindinè komunikacinè arterija, jungianti į Rusijos gilumą nužygiavusią Napoleono armiją. Šiuo keliu nuolatos vyko intensyvus judejimas: žygiavo papildomi kariniai daliniai, keliavo gurguolès su maistu, karine amunicija ir ginklais, čia

\footnotetext{
${ }^{18}$ Ašmenos apskrities paprefekturos 18120722 raštas LLVK. Ten pat, 1. 127-128.

${ }^{19}$ Jokūbo Lokuvickio, Adomo ir Vinco Voinovičiu 18120706 prašymas Ašmenos paprefektūrai. Ten pat, 1. 120 .

20 Vilniaus apskrities gyventojo Stanislovo Jasinskio 18120725 prašymas LLVK. Ten pat, 1. 33; Ukmergès paprefekčio 18120728 raštas VDAK, Ten pat, 1. 169; Užnerio apskrities piliečio Šventožerskio raštas. Ten pat, 1. 156.

${ }^{21}$ Iwaszkiewicz. J. Litwa w roku 1812, s. 152.

22 Корнейчик Е. Белорусский народ в Отечественной войне 1812 года, Минск, 1962, с. 44; О разорении жителей Березинского кантона французкими мародерами с которыми иногда соединились крестьяне, Акты, уздаваемые Виленскою комиссиею для разбора древних актов, с. 273-274; Tymczasowa gazeta Minska, 1812, Nr. 8.
} 
taip pat veikè pagrindiniai ir tarpiniai maisto ir pašaro etapų sandèliai. Savo ruožtu papildoma arterija, jungianti Tilžę ir Rygą, ejo per Žemaitiją.

Lietuvos laikinosios valdžios i̇vairių lygių institucijų dokumentacijoje (ypač Vilniaus departamento) surandame nemažai pranešimų, fiksuojančiu pražygiuojančių dalinių savivaliavimo faktus ir gyventojų patirtus nuostolius. Vèlgi labiausiai nukentejo tos vietovès, per kurias vyko intensyviausias kariuomenės judejimas arba ilgesniam ar trumpesniam laikui buvo apsistoję kariniai daliniai. Vilniaus departamente didžiausias skriaudas patyrè Vilniaus, Ašmenos, Trakų apskričių miestelių ir kaimų gyventojai. Vilniaus apylinkèse (Rūkainiuose, Paneriuose, Rastinėnuose, Sudervèje, Medininkuose) daliniai dažnai elgdavosi vien savo nuožiūra, o, tiksliau sakant, be akivaizdžios būtinybès: nors Vilniuje sandèliuose netrūko nei maisto, nei pašaro, atvirai smurtavo ir plèšè gyventojų turtą. Medininkų valstiečiai pražygiavus Didžiosios Armijos daliniams ir po marodierių siautẻjimo prarado daug naminių gyvulių (paimti jaučiai, karvės ir arkliai) bei neteko pagrindinio turto - 19 namų. Patekę i tokią keblią padèti valstiečiai prašèsi valdžios atsižvelgti i nelaimes ir vienus metus atleisti nuo mokesčių ${ }^{23}$.

Savo ruožtu Trakų apskrities gyventojai skaičiavo nuostolius, patirtus dèl Merkinèje dislokuoto karinio būrio vado majoro de Kusteno veiksmų, kuris nesitenkino vien tik oficialiomis rekvizicijomis, bet vykdè ekspedicijas i aplinkines vietoves (ypač nukentejjo Varẻnos dvaras ir aplinkiniai kaimai) bei reikalavo iš gyventoju piniginių rinkliavų. Tokị elgesi vietinè valdžia tiksliai ịvardijo kaip „neformalų apiplěšimą“. Kitose Vilniaus departamento apskrityse, esančiose atokiau nuo pagrindinių karinių daliniu judejimo maršrutų, tokių atvejų pasitaikydavo gerokai mažiau ${ }^{24}$.

Žemaitijos gyventojai tiesiogiai susidūrẻ su karinių dalinių savavališkais veiksmais, kai paskui 10-aji korpusą žygiavo papildomi daliniai, daugiausia iš Prūsijos, ypatingai pasižymėjo generolo Hermano Deandelso divizijos kariai $^{25}$. Rugpjūčio 30 d. divizijos kariai įvykdè Veliuonos dvaro ir valstiečiuc,

\footnotetext{
${ }^{23}$ Spalio 3 d. sudeginti Medininkų klebonijos pastatai, atimti arkliai, be to, du kartus apiplèšta bažnyčia. Medininkų parapijos kunigo Pranciškaus Ulinskio 18121014 raštas LLVK, LVIA, f. 1532, ap. 1, b. 7, 1. 67; Vilniaus apskrities paprefektūros 1812 09-11 dokumentacija, Ten pat, 1. 70-76, 89-94; Medininkų valstiečių 18121013 prašymas Vilniaus departamento administraciniai komisijai. Ten pat, b. 15, 1. 158; Ašmenos apskrities paprefektūros 181209 18-19, 10 04, 16 dokumentacija, Ten pat, b. 7, 1. 130, 137, 140, 143.

${ }^{24}$ Trakų apskrities paprefektūros 181207 18-28, 08 25, 31 dokumentacija, Ten pat, 1. 112 - 115, 274; Užnerio apskrityje 57 -ojo péstininkų pulko kariai dèl neaiškių priežasčių sudegino (išliko tik klebono namas ir karčema) Slabados gyvenvietę Polocko trakte. Pranciškaus Paškevičiaus 18120931 prašymas Užnerio apskrities paprefektūrai, Ten pat, b. 13, 1. 400.

${ }^{25}$ Pugačiauskas V. Napoleono administracija Lietuvoje, p. 100-101.
} 
anot dvaro valdytojo, ,iki tol negirdètą apiplèšimą“: nuostolių suma dvarui buvo 2 826, 21 auksinas, o valstiečiams - 11 524, 14 auksinų. Batakių valsčiaus žemvaldžiai ir valstiečiai įvertino savo nuostolius - 2559 auksinų suma. Tačiau labiausiai nepasisekè Vilkijos miestelio, dvaro ir gretimų kaimų gyventojams, kurie nuostolius ivvertino net 30180 auksinų suma. Tokia padètis privertẻ Raseinių apskrities valdžią pažadèti mokesčių lengvatas labiausiai nukentejjusiems gyventojams ${ }^{26}$. Beje, Vilkijos ir jos apylinkių gyventojai kentėjo ir vèliau, kadangi miestelyje buvo numatytas tarpinis depo trakte tarp Jurbarko ir Kauno, bei kelio, ateinančio iš Raseinių, tačiau nepasirūpinta įkurti maisto ir pašaro sandèlio, tad pražygiuojantys kariniai daliniai apsistodavo gyventoju namuose po 3-4 kareivius ir reikalavo visapusiško išlaikymo ${ }^{27}$.

Dèl intensyvaus pražygiuojančių dalinių srauto nemažų nuostolių patyre ir Minsko departamento gyventojai, ypač Borisovo apskrities: čia sudeginta 12 kaimų o etapų sandèliai dažnai buvo paprasčiausiai išgrobstomi, iš gyventojų karinès komandos jëga atiminèjo maisto produktus ir pašarus, skirtus Borisovo sandèliui ${ }^{28}$.

Gardino departamente karinių dalinių savivalè, turimais duomenimis, neigavo plataus masto. Čia fiksuojame tik pavienius savavališkų rekvizicijų atvejus atskirose Lydos, Naugarduko, Volkovysko apskričių vietovèse, kurias epizodiškai vykdè 7-asis saksų karių korpusas vadovaujamas generolo Žano Renje, ir 8-asis, vestfaliečiu korpusas, vadovaujamas minèto generolo Vandamo, turintis ypatingą tokios veiklos patirtįi ${ }^{29}$

Apginti gyventojų nuo dalinių savivaliavimo apskričių valdžia neturèjo didesnių galimybių: i josios pastabas paprasčiausiai nebuvo atsižvelgiama, o jai pavaldi žandarmerija buvo per menka jèga. Tik reguliariosios kariuomenės pulkams retkarčiais pavykdavo sutramdyti ir apginti gyventojus nuo įsismarkavusiu

\footnotetext{
${ }^{26}$ Jonas Mikša prarado avị, kiaulę, grūdus, šieną, 2 kepures, vežimą, vašką ir druskos atsargas, iš viso už 142 auksinus ir 6 grašius. Tačiau labiausiai nukentėjo malūninkas, netekęs ne tik maisto produktų atsargų, bet ir namų apyvokos daiktų (sidabrinių stalo įrankių drabužių ir kitokio turto) už 386 auksinus ir 90 grašių. Veliuonos dvaro ir gyventojų nuostolių, patirtų dẻl Deandels divizijos savivaliavimo, suvestine, LVIA, f. 1532, ap. 1, b. 13, 1. 3-7; Batakių valsčiaus nuostolių sąrašas, ten pat, 1. 91; Vilkijos nuostolių sarašas. Ten pat, 1. 107-110.

${ }^{27}$ Kazimiero Dambrovičiaus 18120920 raštas Raseinių paprefektūrai. Ten pat, b. 13, 1. 106.

${ }^{28}$ Краснянский Г. Город Борисов и Борисовский уезд в Отечественную войну 1812 года, Гродно, 1914, с. 7, 33, 38; Об отнятии французами провианта у местного обивателя, Акты, издаваемые Виленскою комиссиею для разбора древних актов, т. 37, с. 206-207; Жалоба еврея Бульфа Двиркихда у которого взято 12 лошадей русскими и 26 французами. Ten pat, p. 211.

${ }^{29}$ Vestfaliečiai „bloga šlove“ pasižymèjo 1809 m. kare Lenkijoje Kališo departamente. Złotkowski D. Miasta departamentu Kaliskiego w okresie Księstwa Warszawskiego, Częstochowa, 2001, s. 51; Историческая записка, Военский К. Min., veik, p. 442-443.
} 
Didžiosios Armijos karių ${ }^{30}$. Akivaizdu, kad toks karinių dalinių elgesys gerokai sumažino palankiai nusiteikusių gyventojų gretas.

Karo pabaigoje Lietuvos gyventojų dar lauke papildomi išbandymai, kurie sietini su Didžiosios Armijos atsitraukimo tragiškomis aplinkybėmis. Iš Rusijos grižtantys demoralizuoti, pakrikę, karo ir žiemos sunkumų išvarginti daliniai, tiksliau sakant, jų likučiai, bei iš paskos jiems besivelkantys atsilikèliai siaubė pakeliui esančias vietoves, ieškodami maisto ir šiltos pastogès. Taigi labiausiai nukentejjo Borisovo, Molodečno, Smurgainių, Vilniaus ir Kauno vietovių gyventojai, ypač mažesnių gyvenviečių. Jas, pasak amžininko, dažniausiai ištikdavo toks likimas: ,naktis buvo šalta ir kitą dieną beveik visi kaimelio trobesiai išnyko sukūrenti laužavietèse ${ }^{\text {“31 }}$. Analogiškas likimas ištiko Borisovo miestą ${ }^{32}$.

Vilniuje buvo sugriauta, apiplesšta ir sudeginta trečdalis viso namų fondo ${ }^{33}$. Panaši situacija susikloste ir Kaune, nors ji pasiekè mažesnis skaičius Didžiosios Armijos karių. Aleksandro Ružancovo duomenimis, Kaune pastatų fondas patyrẻ îvairaus pobūdžio nuostolių: suniokota 26,3 proc. mūrinių ir 16,8 proc. medinių namų, taip pat 5 vienuolynai bei 5 bažnyčios. Taigi beveik pusė namų, t. y. iš 271 namu nukentejo $114^{34}$. Šiuo atveju vẻlgi labiausiai pasiseke Šiaulių ir Telšių apskričių gyventojams, kadangi Makdonaldo korpuso daliniai traukèsi tvarkinga rikiuote, be didesnès panikos, o maistu dažniausiai apsirūpindavo iš sukauptų atsargų etapų sandèliuose ${ }^{35}$.

Didžiosios Armijos masinès savivalès rezultatus tiesiogiai galima susieti su nužydytų ir dingusių be žinios civilių gyventojų, apiplěštų bei sugriautų ir sudegintų rūmų ir dvarų, valstiečių dūmų, sunaikintų pasèlių, miestiečių gyvenamuju namų, o taip pat bažnyčių, vienuolynų bei ūkinès paskirties statinių (malūnų, smuklių, duonos kepyklų, bravorų, sandèlių, arklidžių, krautuvių ir t.

\footnotetext{
${ }^{30}$ Ašmenos apskrities paprefektūros 18121116 raštas, LVIA, f. 1535, ap. 1, b. 7, 1. 143; Užnerio apskrities paprefektūros 18121201 raštas. Ten pat, l. 160-161.

${ }^{31}$ Pasitraukimas per Lietuvą. Paskutiniai Christian Wilhelm von Faber du Faur 1812 metų karo žygio vaizdai Lietuvoje. Reklaitis P. Min., veik, p. 311.

${ }^{32}$ Краснянский Г. Min., veik, p. 57.

${ }^{33}$ Vilniaus miesto nekilnojamojo turto nuostolių, patirtų per prancūzmetį, suvestinė, LVIA, f. 937 , ap. 1, b. 165, 1. 26-30.

${ }^{34}$ Publikuojamas Kauno miesto visuomeninių, gyvenamujų ir kitokios paskirties namų, nukentėjusių prancūzmečiu sąrašas. Ružancovas A. Gaisrai Kaune 1812 metais (prancūzmečiu), Savivaldybè, 1930, Nr. 4, p. 22-24; Ведомость сколько в городе Ковне клашторов, церквей, домов..... Декабря 29-го дня 1812 года, Виленский Временик, книга 5, ч. 1, с. 224; Рахманин С. Наполеон I и великая армия в Ковенской губернии, Ковно, 1908, с. 18-19.

${ }^{35}$ Rekvizicijų, vykdytų napoleonmečiu Šiaulių apskrityje, sąrašas, LVIA, f. 392, ap. 1, b. 23, 1. 201.
} 
t.) statistika. Kadangi „Generalinèje lentelèje“ yra suregistruoti duomenys apie abiejų priešininkų ịvykdytus neteisètus veiksmus prieš vietinius gyventojus, dèl tokios bendros statistikos neįmanoma tiksliai suskaičiuoti Didžiosios Armijos savivaliavimo padarytų nuostolių, tačiau komisijos darbo protokoluose abiejų armiju padaryti „nusižengimai“ fiksuojami atskirai. Juose, be abejonès, gerokai didesnis vaidmuo tenka Didžiajai Armijai. Tai ypač atsispindi sudegintų ir apiplesštų pastatų statistikoje, tačiau vėlgi reikia pastebėti, kad nemažai šių nuostolių dera priskirti karo pabaigai, t. y. vertintinas ir kaip abiejų priešininkų susidūrimų rezultatas. Pavyzdžiui, Baltupių palivarką niokojo ne tik pracūzų daliniai, betgi ir rusų kazokai, sudeginę malūną ir tris valstiečių kiemus, o Vidžius spalio $31 \mathrm{~d}$. užpuolę kazokai sudegino 79 namus, 22 krautuves bei šieno ir grūdų sandèlius. Baltstogès miesto 1812 m. karo nuostoliai, komisijos vertinimu, sudare 15861 rb. Sidabru ir 21 kapeikas, iš kurių Didžiajai Armijai priskirtina 13041 rb. 62 kap. sidabru suma, o Rusijos kariuomenei 2819 rb. 59 kap. sidabru suma ${ }^{36}$.

Ašmenos apkrities gyventojai, remiantis minètos komisijos surinktais duomenimis, patyrė didžiausius nuostolius: sudeginti 2189 (tarp jų 3 bažnyčios, 2 rūmai), apiplèšti 21 pastatas. Vilniaus apskrityje sudeginta 830, apiplèštas 281 pastatas (daugiausia 207 valstiečių dūmai). Breslaujos apskrityje sudeginta 519 (iš jų daugiau kaip puse -217 valstiečiu gyvenamieji namai ir ūkiniai trobesiai), apiplèšti 157 pastatai. Mažiausiai nukentejo Upytės apskritis, atitinkamai 19 ir 11 pastatǔ. Iš viso Vilniaus departamente sudeginti 3 rūmai, 5 bažnyčios, 3 klebonijos, 1 cerkvè, 230 dvarininkų ir bajoru gyvenamujų namų, 103 miestiečių gyvenamosios patalpos, 67 palivarkai, 906 valstiečių dūmai ir 226 valstiečių gyveniamieji trobesiai bei daugiau kaip 2000 ūkinès paskirties objektų, o apiplěšta - 1370 37 .

Gardino departamento apskričių nuostolių statistika byloja, kad gyventojai patyrè gerokai mažesnių nuostoliu, o labiausiai nukentejjo Volkovysko apskritis, kurioje sudegè 151 gyvenamasis namas ir apie 1000 įvairios paskirties pastatu, tačiau Lydos apskrityje sudeginti vos 34 gyvenamieji namai ir 48 kitos paskirties pastatai bei apiplěšta vos 21 sodyba $^{38}$. Minsko ir Baltstogès departamentu duomenų nepavyko rasti.

Taigi galima teigti, kad Didžiosios Armijos vykdyta savivaliavimo prakti-

\footnotetext{
${ }^{36}$ Iwaszkiewicz. J. Rejestra i indemnizacja strat wojenych na Litwie po roku 1812, tabl. III, s. 146. Prancūzų padaryti nuostoliai Baltupiams ịvertinti 4194 rb. sidabru, o rusų kazokų 411 rb. sidabru ir 99 kap. Baltupių palivarko nuostolių suvestinè. Ten pat, f. 392, ap. 1, b. 3029, 1. 25; Vidžių municipaliteto 18121118 raštas LLVK. Ten pat, f. 1532, ap.1, b. 7, 1. 166.

${ }^{37}$ Генеральная табель Nr. 318, Виленский Временик, т. 2, с. 275.

${ }^{38}$ Генеральная табель Nr. 319. Ten pat, t. 2, p. 376.
} 
ka tapo vienu iš svarbiausių veiksnių, nulemusių Lietuvos gyventojų didžiulius nuostolius: pirma, civilių gyventojų žudynès, antra, materialinè žala praradus pagrindinius pragyvenimo šaltinius, taigi žmonès buvo priversti kęsti nepriteklių ir balansuoti ties skurdo riba.

\section{Rekvizicijų našta}

Antruoju svariu veiksniu, pareikalavusiu iš gyventojų didelių materialinių išlaidų, galima drąsiai i̇vardyti karo rekvizicijas. Kaip žinoma, Rusijos karinė vadovybė rekvizicijų iš gyventojų būdu prieš pat karą sukaupė didžiulius maisto ir pašaro sandèlius. Pirmosiomis karo savaitėmis Lietuvos gyventojai susidūrè su realiais sunkumais, kuriuos nulèmė ne tik daugiatūkstantinès Napoleono armijos masinis savivaliavimas, bet ir skubios rekvizicijos stokojant maisto ir pašaro ${ }^{39}$. Armijos aprūpinimas maistu ir pašarais išliko aktualia problema per visą karo laikotarpi. Napoleonas tai sprendẻ vietinių gyventojų sąskaita skelbdamas gausias rekvizicijas, kurių adminstravimu rūpinosi Lietuvos Laikinoji Vyriausybė bei prancūzų civilinè ir karinè administracija Lietuvoje. Akivaizdu, kad visų rekvizicijų nebeįmanoma suskaičiuoti dèl jų gausos, o atskirais atvejais duomenų trūkumo, todèl dèmesị sukoncentruosime ị didžiausias, kurios leis susidaryti realų vaizdą apie rekvizuotų produktų apimtį ir mastą.

Tokių svarbiausių rekvizicijų, paskelbtų Napoleono ir LLVK įsakais, yra keturios. Pirmoji - isakyta skubiai aprūpinti sandèlius, ikkurtus Vilniuje ir kitose vietovése, maistu ir pašaru bei surinkti 2000 arklių, skirtų lengvajai kavalerijai, artilerijai ir transporto vežimams traukti, taip pat nurodyta ịvykdyti kontribuciją iš Žemaitijos (t. y. nuo 20 dūmų derèjo pristatyti po 1 arkli) į Kauną vẻlgi dviem tūkstančiams arklių, skirtų artilerijai ir karinès amunicijos ekipažams. Tai reiškè, kad gyventojai privalëjo pristatyti grūdų atsargas, pasiliekant tik asmeninėms reikmėms po nedideles kruopų ir miltų atsargas. Minsko departamente tokios rekvizicijos pavyzdys

\footnotetext{
${ }^{39}$ Pirmosiomis karo dienomis iš vietinių gyentojų buvo pareikalauta išmaitinti: Napoleonas Vilniuje pareikalavo 100000 maisto davinių, Makdonaldas nurodė Raseiniuose išmaitinti apie 40000 karių, o Telšiuose 600000 davinių džiūvèsių, 300 statinių degtinès, 1500 alaus, 20 statinių acto, po 50000 davinių avižų, šieno ir šiaudų, 600 jaučių, 400 vežimų. İsakas dèl panašaus dydžio rekvizicijų pasiekẻ ir Šiaulių apskrities valdžią. Maršalas Udino Ukmergès apskrityje liepė surinkti maistą 45000 karių, kurie galètų maitintis 15 dienų, Vestfalijos karalius Žeromas Gardine pareikalavo 500000 maisto porcijų davinių. Tiesą pasakius, neaišku, kiek pavyko surinkti. Dundulis B. Lietuva Napoleono agresijos metais, p. 52, 111; Iwaszkiewicz J. Litwa w roku 1812, s 236; Орловский Е. Гродненская губерния в 1812 году, Гродно, 1912, с. 25; Le Maréchal Macdonald, Revue Histoire de l'armée, Paris, 1971, no. 2 , p. 59 .
} 
- liepos 25 d. Iš Borisovo apskrities, turinčios 46950 gyventojus, pareikalauta 2306 statinių miltų, 415 kviečių, 4604 avižų, 5216 pūdų šieno ir šiaudų, 14526 gorčius degtinès, 1725 jaučių ${ }^{40}$. Gardino departamente 6 pagrindinių bei 3 rezervinių magazinų Gardine, Lydoje, Naugarduke aprūpinimui pagal prancūzų karo komisaro Barthomeufo issaką turèjo būti sukaupta kiekviename ne mažiau kaip po 2000 maisto atsargų daviniams ir pašaro norma 700-800 arkliams ${ }^{41}$.

Antroji - naujojo derliaus pyliava, vadinamasis „savanoriškas paaukojimas“, kuris turèjo būti ịvykdytas iki spalio 1 d., privalu surinkti tokị kiekị: 24232 statines rugių, tiek pat avižu̧, 1376 statines grikių arba kitų kruopu, po 128644 pūdų (1 pūdas $-16,4 \mathrm{~kg}$ ) šieno ir šiaudú. Dẻl gero derliaus ši rekvizicija buvo beveik ịvykdyta.

Trečioji - rugsejjo $1 \mathrm{~d}$. Napoleono paskelbta rekvizicija, pagal kurią 4 departamentams derejo pristatyti po 600000 centnerių rugiu ir avižu, po 15000 šiaudų ir šieno ir 30000 jaučiu i rezervinius sandèlius. Išimtis taikoma tik valstiečiams daržininkams, bežemiams bei nukentèjusių dūmų šeimininkams. Rekvizicijos vykdymo terminas - 3 mèn. grūdams ir pašarui, 6 mėn jaučiams surinkti. Ji nebuvo iki galo įvykdyta.

Ketvirtoji didžiulių rekvizicijų banga nusirito per kraštą, kai Napoleonas isakè kuo skubiau sukaupti dideles maisto, pašaro (maždaug 4 žiemos mėnesiu laikotarpiui po 100000 - 120000 maisto davinių vienai dienai) ir kuro atsargas Vilniuje, kadangi tikejjosi be didelių nuostolių pasiekti miestą ir čia, atrèmus prieša, sèkmingai peržiemoti. Sprendžiant iš Prancūzijos užsienio reikalų ministro H. B. Marė pranešimo atvykusiam i Medininkus Napoleonui, pasiektas rezultatas buvo gerokai kuklesnis: Vilniaus sandèliuose pavyko sukaupti atsargų, kuriu pakaktų 100000 karių 40 dienų $^{42}$. Taigi gyventojai vienu metu privalèjo vykdyti kelias maisto ir pašaro rekvizicijas.

Kita vertus, reikia turèti omenyje ir tai, kad būta daugybẻ kitų mažesnių i̇vairaus pobūdžio rekvizicijų kariniams poreikiams tenkinti, inicijuotų vietinių laikinosios valdžios institucijų arba prancūzų intendantų, tepaminėsime tik keletą: spalio mènesį prancūzai reikalavo papildomai 1000 arklių kavalerijai, karo ligoninèms Vilniuje pristatyti 2875 jaučius, vẻliau dargi surinkti 2 gorčius grūdų nuo kiekvieno dūmo iš 6 apskričių, o nuo kiekvienos daryklos po 15 gorčių degtinès ${ }^{43}$. Yra žino-

\footnotetext{
${ }^{40}$ Корнейчик Е. Min., veik, p. 51.

${ }^{41}$ Историяеская записка, Военский К. Min., veik, p. 438.

42 Iwaszkiewicz J. Litwa w roku 1812, s. 300, 302.

${ }^{43}$ LLVK paskirste taip: 775 - Vilniaus departamentui, 600 - tiekejui Micheliui, 1500 - Gardino, Minsko ir Baltstogès departamentams). L'etat de requisitions mises sur les districts du Departament de Wilno, pour livrer des boeufs pour les hopitaux de la grand armée ą Wilna, LVIA, f. 1532 ap. 1, b. 14, 1. 234-235; Dundulis B. Lietuva Napoleono agresijos metais, p. 113.
} 
ma, kad napoleonmečiu Šiaulių apskrities valdžią pasiekė apie 17 prancūzų karinès ir Lietuvos laikinosios valdžios ịsakų dẻl įvairaus pobūdžio rekvizicijų ${ }^{44}$.

Aiškinantis rekvizicijų apimti gelbsti Vilniaus centrinio sandèlio statistiniai duomenys, kuriuose pateikiami gautų ir išduotų grūdu, miltű, degtinès, jaučiu, šiaudų šieno kiekis, - buvo surinkta rekvizicijų būdu iš Vilniaus departamento apskričiu bei Naugarduko, Lydos, Baltstogès apskričių. Taigi čia buvo kaupiamos pirmos būtinybės, strateginès, atsargos, skirtos Napoleono kariniams daliniams maitinti, taip pat išduodamos Vilniaus municipalitetui, kuris naudojo produktus (labiausiai naudota mėsa ir dègtinè) karo ligoninėse. Iki naujojo derliaus sandèlio direktoriaus Puzynos žiniaraštyje užfiksuotas didžiausias pašarų ir jaučių prièmimo ir išdavimo kiekis ${ }^{45}$.

Per laikotarpi nuo liepos $10 \mathrm{~d}$. iki spalio $9 \mathrm{~d}$. sandèlyje buvo atgabenta rekvizicijų iš 14 apskričių: 1605 jaučiai ir 19 avių, 2659 statinès rugių, 11 kviečių, 221 miežių, 769 avižuc, 26 grikių, 1085 statinès ruginių miltų, 34 kruopų, 6027 gorčiai degtinès. Visa tai buvo išduota, išskyrus jaučius (liko 757). Didžiausią paklausą turejjo rugiai ir avižos (išdavimo norma vidutiniškai iki 100 statinių per dieną) bei pašarai, kurie sandèlyje niekada neužsilikdavo. Intensyviai gyventojai rekvizicijas vežè ị Vilnių spalio mèn., o lapkričio mèn. sandèlio maisto produktų ir pašaro apyvarta gerokai sulètėjo, paskutine išdavimo diena - gruodžio 6 d. ${ }^{46}$

Ši statistika liudija apie didžiulę maisto, pašaro ir kitų rekvizicijų apimti, tenkančią gyventojų ūkiams. Laikinoji valdžia, siekdama patenkinti karinius poreikius, buvo priversta rekvizicines prievoles taikyti dvarininkams ir bajorams. Ryškiausias pavyzdys - pyliavos rekvizicija, kurios vykdymas buvo paskirstytas po lygiai žemès savininkams ir valstiečių ūkiams taip: rugiai ir avižos po 100 litrų ( 2 osminas, t. y. po 8 ketvirčius Vilniaus statinès - 407 litrai), šieno ir šiaudu po 2 pūdus, kruopų ir žirnių po 2 gorčius. Tačiau pagrindinè rekvizicijų našta atiteko valstiečių kiemams, atleidžiant nuo pagrindinių rekvizicijų tik bežemius bei sugriautų ar sudegintų dūmų valstiečius.

Liepos mènesị, remiantis Šiaulių apskrities pavyzdžiu, kiekvienas dūmas turèjo pristatyti 62 pūdus šieno, rugsèji - 5 gorčius miltų ( 1 lietuviškas gorčius $-2,75$ litro), 13,3 gorčiaus avižuc, 2 pūdus ir 15 svarų (1 svaras -370 g.) šieno ir šiaudų, po septintadalį kvortos (1 kvorta - 1,4 litro) degtinès ir nuo 12 dūmų po

\footnotetext{
${ }^{44}$ Rekvizicijų, vykdytų napoleonmečiu, Šiaulių apskrityje sąrašas, LVIA, f. 392, ap. 1, b. 23, 1. 200-201.

${ }^{45}$ Rugsèjo mèn. pirmosiomis savaitėmis sandèlyje tebuvo vos 210 statinių rugių, po 8 statines miežių ir kviečiu bei apie 100 jaučių. Naugarduko, Lydos, Gardino, Baltstogès ir Volkovysko apskritys tiekè tik jaučius. Vilniaus centrinio magazino statistiniai duomenys. Ten pat, f. 1532, ap. 1, b. 11, 1. 85, 96-117. ${ }^{46}$ Vilniaus departamento gyventojai rekvizicijas vežè iki pat prancūzų sugrị̌imo, o gruodžio 6 d. javų likutis sudarè 3598 statines. Ten pat, 1. 140-142, 190-193.
} 
1 jauti. Spalio mėn. pradžioje karo ligoninėms VDAK pareikalavo 2 gorčių (1 gorčius - 3 litrai) kviečiu, vèliau pristatyti į etapų sandèlius Alytuje ir Merkinèje nuo kiekvieno dūmo po 156 litrų miltų, 250 litru avižų, šieno 22 pūdus, o nuo 6 dūmų 1 jauti. Kaip matyti iš šios statistikos, rekvizicijos valstiečių ūkiui buvo sunki našta, pavydžiui, rekvizuojamo šieno kiekis prilygo 4 karvių išlaikymui ${ }^{47}$.

Karo nuostolių statitiska liudija, kad Vilniaus departamente naminių gyvulių nuostoliai, iskaitant ir prievarta atimtus, sieke $30 \%-60 \%$ nuo bendro gyvulių skaičiaus, pavyzdžiui, kas antras kiemas prarodo po jauti, o Ašmenos ir Vilniaus apskrityse šie rodikliai siekè apie 1,3 jaučio. Panaši situacija susiklostẻ Gardino departamento apskrityse ${ }^{48}$. Taigi kraštą nuo didesnių bẻdų išgelbèjo 1813 m. geras derlius, o Vilniuje nuo rudens duona ir kiti maisto produktai buvo pradèti pardavinèti ikikarinèmis kainomis ${ }^{49}$.

Vilniaus, turinčio Didžiosios Armijos svarbiausios užnugario karinès bazès bei politinio ir administracinio centro statusą, gyventojams teko vykdyti specifines prievoles, pavyzdžiui, išlaikyti prancūzų karinès ir administracinès valdžios aukštus pareigūnus, teikti pastotes, išlaikyti karo ligonines (irengti patalpas, aprūpinti inventoriumi, pasirūpinti jo išlaikymu) ${ }^{50}$.

Be to, reikia pastebèti, kad gyventojams begales rūpesčiu sukèlė transportavimo rekvizicijos. Surinkti maisto produktai ir pašarai turejjo būti operatyviai pristatomi i apskričių, Vilniaus ir Kauno centrinius ir netgi kitų departamentu sandèlius. Šiam sunkiam darbui atlikti reikejjo nemažo skaičiaus arklių, jaučių ir vežimu, o žmonès buvo priversti ilgam palikti savo ūkius. Padètị blogino daugybė faktorių: arklių stoka, blogi keliai, dažni atvejai, kai transporto priemones karinè valdžia užlaikydavo arba tiesiog atimdavo ir priversdavo vykdyti kari-

\footnotetext{
47 Žr. nuor. 44; Suskaičiuota, kad vienai karvei reikejjo 18 pūdų šieno. Jučas M. Baudžiavos irimas Lietuvoje, Vilnius, 1972, p. 115.

${ }^{48}$ Karo nuostoliu skaičiavimo komisijos duomenimis, Vilniaus departamento gyventojai (115 796 kiemai) patyrè tokius nuostolius: 99605 arkliai, 61183 jaučiai, 13590 karvių, 224166 avys, 120961 kiaulès. Pavyzdžiui Breslaujos apskrities gyventojai neteko $61 \%$ arklių, $53 \%$ jaučių, 58 \% karvių ir 54 \% kaiulių. Gardino departamento (89 953 kiemai) neteko 32209 arklių, 70297 jaučių, 129038 karvių, 165641 avių, 72417 kiaulių. Генеральная табель, nr. 318, 319, Виленский Временник, кн. 5, ч. 2, c. 275 , Hedemann O. Historia powiatu Brasławskiego, Wilno, 1930, s. 158; Vilniaus departamento kiemų skaičius nurodytas pagal 1795 m. liustracijos duomenis, kadangi „Generalinèje lenteleje“ Ukmergès ir Šiaulių apskrities kiemai nèra suskaičiuoti. Vilniaus gubernijos 1795 m. kiemų liustracijos duomenys, LVIA, f. 1532, ap. 1, b. 6, 1. 6.

${ }^{49}$ Frankas J. Atsiminimai apie Vilnių, Vilnius, 2001, p. 419.

50 Jurginis J, Merkys V, Tautavičius A. Vilniaus miesto istorija, Vilnius, 1968, p. 231. Plačiau apie miestiečiams skirtas rekvizicijas žr. V. Pugačiauskas. Napoleonas ir Vilnius: karinio gyvenimo kasdienybės bruožai, Vilnius, 2004, p. 45-51.
} 
nio transportavimo užduotis. Ypatingai sunki našta ši rekvizicija buvo Žemaitijos, Upytės apskrities valstiečiams, kadangi jie vykdẻ papildomus rekvizicinius isipareigijimus - tiek laikinosios valdžios, tiek Makdonaldo ar jam pavaldžių dalinių vadų isakus dẻl maisto produktų, pašaro ir transportavimo rekvizicijų. Dar daugiau nuo rugpjūčio 12 d. iki spalio vidurio jie aptarnavo artilerijos (130 pabūklų) ir amunicijos pervežimo ị Rygą rekviziciją, kuriai ịvykdyti prireikè ne daug laiko, bet ir apie 5000 arklių $^{51}$. Taigi pervežimo rekvizicijos apimčių būta tokių, kad kiekvieno ūkio šeimininkas, turintis arkli arba jauț ir vežimą, buvo priverstas vykdyti prievolę po keletą kartų.

Laikinosios Vyriausybės Maisto ir magazinų komitetas, vadovaujamas Stanislavo Soltano, tiesiogiai atsakingo už rekvizicijas, prancūzų valdžios nurodymu, sukūrè ištisą „,magazinu““ tinklą. Svarbiausiuose traktuose veikè centriniai etapų sandèliai, papildomi tarpiniai „magazinai“, išdèstyti maždaug per vienos dienos žygiavimo atstumą, bei jau minèti rezerviniai sandèliai ${ }^{52}$.

Tiesą pasakius, didžiosios daugumos rekvizicijų reikiamo kiekio įvykdymas buvo sunkiai įmanomas dèl gausybės įvairaus pobūdžio priežasčių. Pirmoji ir, galima sakyti, pagrindinė - Napoleono armijos poreikiai gerokai viršijo ūkinį krašto potencialą, tiksliau sakant, gyventojų ūkio galimybės pateikti papildomą, didesni maisto produktų kieki buvo itin ribotos, beje, tai pastebėjo ir Napoleono administracijos Lietuvoje pareigūnai. Apie tai liudija valstiečiu atsisakymai vykdyti maisto produktų pristatymą ir mokèti mokesčius, laikinosios valdžios institucijų raginimai skelbiami bažnyčiose, dẻl rekviziciju vykdymo atsakomybès, bei rekvizicijų išieš-

\footnotetext{
51 Об изготовлении 12000 подвод для перевозки амуниции из Сморгонь в Оршу, Военский K. Min., veik, p. 186; Савицкий В. Упитсний уезд в период французкой оккупации (1812), Lietuvos TSR Aukštujų mokyklų mokslo darbai (toliau - AMMD), Istorija, 1978, t. XVIII, sąs 2, p. 70-71; Dundulis N. Napoléon et la Lituanie en 1812, p. 225-226; Pugačiauskas V. Napoleono administracija Lietuvoje, p. 107, 110. Artilerijai traukti 2 dūmai privalejo paskirti dviem arkliais traukiamą vežimą. Rekvizicijų, vykdytų napoleonmečiu, Šiaulių apskrityje sąrašas, LVIA, f. 392, ap. 1, b. 23, 1 . 200-201.

52 Napoleono nurodymu Vilniaus departamente pirmieji sandèliai pradejo veikti Kauno-Vilniaus trakte (Vievyje, Žiežmariuose, Rykantuose), pačiame Vilniuje, taip pat Merkinejje ir Alytuje specialios paskirties artilerijos parko, kavalerijos ir karinių ekipažų sandèliai. Pastarųjų vietovių magazinams produktus privalejo tiekti ne tik Vilniaus, bet ir Gardino departamentas, o atskirais atvejais ir Varšuvos kunigaikštystès Lomžos Magazinų tinklas veikẻ ir Žemaitijoje apskričių centruose ir prie pagrindinių traktų ịsikūrusiose vietovèse. Kelyje iš Vilniaus į Ašmeną tarpiniai magazinai veikè Medininkuose ir Smurgainyse. Minsko departamente, mūsų žiniomis, centriniai magazinai veikẻ Minske, Borisove, Vileikoje, Igumene ir kitose mažesnèse gyvenvietėse. LVIA, f. 1532, ap. 1, b. 157-158; Dundulis B. Napoléon et la Lituanie en 1812, p. 285-286; Dundulis B. Lietuva Napoleono agresijos metais p. 112, 115; О сборе в магазины фуража, Акты, издаваемые Виленскою комиссиею для разбора древних актов, т. 37, с. 202; Корнейчик Е. Min., veik, p. 51.
} 
kojimas pasitelkus karinę jègą ${ }^{53}$. Paminėsime ir dar keletą konkrečiu pavyzdžių: 1811 m. grūdinių kultūrų nederlius, rusų kariuomenès prieš pat karą vykdytos rekvizicijos, vẻliau rekvizicijų transportavimo sunkumai dél jaučių ir arklių stokos.

Keblią situaciją švelnino tik naujojo derliaus pyliavos bei Vyriausybės sudaryti kontraktai su paskui armiją žygiuojančiais tiekẻjais, vietiniais bei užsienio pirkliais, kurie galèjo operatyviai pristatyti reikiamą maisto kiekị ir pašaro atsargų iš vietovių, neįtrauktu i karo zoną. Tačiau tam reikejjo sukaupti nemažus finansinius išteklius, savaime suprantama, iprastinių ir naujai įvedamų mokesčiu būdu, pavyzdžiui, vien pirkliui Micheletui už 1000 statinių rugių pristatymą derejjo sumokèti per du mènesius pagal suderintą grafika, iš viso $16000 \mathrm{rb}$. sidabru. Ypač dažnai laikinoji Vyriausybè ir Vilniaus departamento administracinè komisija naudojosi tiekejju paslaugomis iki naujojo derliaus ${ }^{54}$.

Nuo rudens Lietuvos gyventojai privalėjo išlaikyti ir laipsniškai besikuriančios Lietuvos reguliariosios kariuomenès pulkus. Laikinoji Lietuvos Vyriausybė spalio 5 d. paskelbè tvarką, pagal kurią lietuviški daliniai aprūpinami maisto produktais iš Didžiajai Armijai skirtų sandèlių. Tais atvejais, jeigu dalinio dislokacijos vietoje nèra maisto sandèlio, ji ịpareigojo vietinę valdžią ikurti naujus, kaip ir pasirūpinti dalinių aprūpinimu, kai jie keičia dislokacijos vietą ${ }^{55}$. Iki to momento, kaip rodo 17-ojo kavalerijos pulko, vadovaujamo pulkininko Mykolo Tiškevičiaus, pavyzdys, kai kariai savavališkai rekvizavo Kupiškio miestelio gyventojus atimdami iš jų maisto produktus, pašarus bei vežimus su arkliais, lietuviški reguliariosios kariuomenės daliniai kaskart buvo priversti prasimaitinti savo jègomis ${ }^{56}$. Kauno municipalitetas 21 Lietuvos kariuomenès pėstininku pulko bataljoną (860 žmonių), apsistojusị miesto prieigose, turẻjo aprūpinti rei-

\footnotetext{
${ }^{53}$ Laikinosios komisijos raštas Vilniaus departamento administracijai dèl priemonių prancūzų kariuomenei aprūpinti, Lietuvos TSR istorijos šaltiniai. Vilnius, 1955, t. 1, p. 403; Савицкий В. Волнения крестьян в Упитском уезде в 1812 г., АMMD, Istorija, Vilnius, 1964, t. 7, p. 165; Generolas Bronikovskis viename iš savo kreipimęsi grasino, kad gyventojams nevykdantiems nustatytų rekvizicijų i Minsko centrinį sandèlį, bus atsiusta kareivių pastotè. Обявление генерала Брониковского о неакуратной доставке продоволствия, Военский К. Min., veik, p. 381, 463-464;

${ }^{54}$ Laikinoji Vyriausybė patenkino Vilniaus departamento Administracijos komisijos prašymą sudaryti sutartis su tiekèjais dèl avižų pirkimo. LLVK 18120908 posėdžio nutarimas. Rusijos valstybinis senujjų aktų archyvas, f. 12, b. 262, 1, 22; LLVK prekybinių sutarčių 181208 protokolai, LVIA, f. 1532, ap. 1, b. 7, 1. 410, 425; VDAK prekybinių sutarčių 1812 06-09 protokolai. Ten pat, b. 11, 1. 320, 322, $336,360,392$.

55 Правила о продоволствии Литовского войска, Военский К. Min., veik, p. 196.

${ }^{56}$ Kupiškio dvaro valdytojo 18120903 raštas Ukmergès apskrities paprefekčiui, LVIA, f. 1532, ap. 1, b. $7,1.172$
} 
kmenimis, skirtais ruošti maistui lauko sąlygomis ${ }^{57}$.

Be minètų šiu pagrindinių rekvizijų, Lietuvos gyventojai vykdè ir kitokius darbus, bene daugiausiai žmonių prancūzų karinès valdžios pageidavimu dirbo fortifikacinių įrengimų darbų Vilniuje ir Kaune. Šiuose miestuose vasaros ir rudens mėnesiais apkasų kasimo darbus Kaune (Šančiuose) dirbo iki 1200 gyventojų $^{58}$. Kaip žinoma, Vilniuje, dešiniajame Neries krante, prancūzai įrenginėjo dviejų linijų gynybinę poziciją, skirtą artilerijai ir kariams, čia dirbo šimtai žmonių iš Ašmenos, Trakų, Ukmergès ir Vilniaus apskričių. 100 žmonių savo ruožtu kasė apkasus Nemenčinėje ${ }^{59}$. Vilniaus apskrities valstiečiams dažnai teko palikti savo ūkius, kadangi buvo varomi plukdyti sielių Nerimi bei traukti botų su maisto atsargomis ${ }^{60}$. Taigi napoleonmečiu Lietuvos gyventojus užgulè sunki rekvizicijų našta, kai vienu metu reikèjo vykdyti daugybę ivvairaus pobūdžio ir didžiulès apimties rekviziciju, dažniausiais viršijančių jų ūkių potencialias galimybes.

\section{Mokesčiai: iprastiniai ir specialieji}

Laikinosios Vyriausybės galimybės aprūpinti Didžiosios Armijos bei šalies kasdieninius poreikius smarkiai padidejjus karinėms išlaidoms (Lietuvos reguliariosios kariuomenès dalinių formavimas) pirmiausiai rèmėsi finansiniais ištekliais, surenkamais mokesčiu pavidalu. Tačiau prabėgus vos vienam ménesiui Finansų komitetas nusprendẻ realizuoti radikalius ir netradicinius būdus, siekiant skubiai papildyti tuščią biudžetą. Tai reiškè, kad mokestinė bazè išplečiama ir neapmokestintų luomų sąskaita. Svarbiausias buvo vadinamasis asmeninis ,,vienkartinès aukos“ mokestis, kuri privalëjo mokèti visi gyventojai, nepriklausomai nuo luomo, tikybos, tautybès, suskirstyti i 11 kategorijų. Mažiausias fiksuotas mokestis siekè vos 15 grašiu, kuriuos privalejjo sumokèti valstiečiai, neturintys savo pajamų ir bernai, o didžiausias mokestis -500 auksinų suma - buvo paskirtas dvarų, turinčių 1000 kiemų, savininkams arba nuomotojams, taip pat nefik-

\footnotetext{
${ }^{57}$ Majoro Kozickio 18121020 raštas Kauno municipalitetui. Ružancovas A. Iš Kauno miesto valdybos archyvo 1812-1813 metų bylų, Karo archyvas, Kaunas, 1928, t. 4, p. 103.

${ }^{58}$ Kauno apskrities paprefektūros 181209 02, 10 raštai VDAK, LVIA, f. 1532, ap. 1, b. 14, 1. 420423.

${ }^{59}$ Fortifikaciniai darbai tęsèsi nuo liepos mėnesio iki vèlyvo rudens ir ịprastai vienu metu dirbo apie 800 žmonių. Vilniaus apskrities paprefektūros 181208 25, 10 20, 27 raštai. Ten pat, 1. 401, 410, 413; Pugačiauskas V. Napoleonas ir Vilnius: karinio gyvenimo kasdienybės bruožai, p. 32-33.

${ }^{60}$ Rugsejo menesị 100 žmonių traukè 23 botus Nerimi iš Kernavès ị Vilnių. Vilniaus apskrities paprefektūros $181208-09$ raštai. LVIA, f. 1532, ap. 1, b. 9, 1. 394, 399, 411.
} 
suotam mokesčiui priskirti „kapitalistai““ atskaičiuojant 1/7 dali kapitalo pajamų ${ }^{61}$.

Lietuvos laikinoji valdžia, ivesdama ši mokestį, planavo papildomai surinkti apie 3-4 milijonus auksinų, tačiau nepavyko aptikti tikslių duomenų, kiek pinigu iplauke i iždą, aišku viena, kad nuolatinių rekvizicijų ir savivaliautojų nualintame krašte didžiulè pinigų suma negalèjo būti surinkta operatyviai, be to, buvo numatytas ilgas vienų metų surinkimo laikotarpis. Kita vertus, surinkta suma neišsprendè pinigų stygiaus problemos ir Napoleonas buvo privertas skirti 500000 frankų sumą Lietuvos kariniams daliniams formuoti ${ }^{62}$.

Finansinių lěšų trūkumas privertẻ Vyriausybę žengti dar vieną žingsnị ir apmokestinti specialiuoju mokesčiu tik dvasininkų luomą, tiksliau sakant, gauti papildomų pajamų atgaivinant $1789 \mathrm{~m}$. Abejų Tautų Respublikos Seimo priimtą vadinamaji bažnytini mokesti, susidedantị iš dviejų dalių: fiksuotos sumos ir 5 \% nuo gaunamu pajamų per 4 metus pagal nustatytas 9 kategorijas. Pirmajai priskirti metropolitai ir achivyskupai turejo sumokèti 1000 auksinų ir 5\%,6-aja, gausiaisią, kategoriją sudarè parapijų kunigai, kurie, priklausomai nuo metiniu pajamų sumos, privalejo sumoketi po $10,30,100$ arba 250 auksinų ir po $5 \%$, i paskutinę kategoriją pateko vienuolynai, kuriems tebuvo skirtas tik $5 \%$ mokestis. Manoma, kad surinkta suma buvo nedidele $\dot{e}^{63}$.

Vilniaus miesto municipalitetas, turėdamas savivaldos teisę, iždo deficito problemas sprende savaip - priverstine tvarka pasiskolindamas iš turtingiausių miestiečių nuo 1000 iki 6000 auksinų, priklausomai nuo jų metinių pajamų. Tokiu būdu pavyko surinkti 112333 iš planuotų 130000 auksinų ${ }^{64}$. Taigi šiai gyventojų grupei derejo mokèti valstybinių ir vietinių mokesčių dvigubą naštą. Reikia pastebėti, kad būta nemažai specialių mokesčių visiems gyventojų luomams, susijusių su kavalerijos ir pėstininkų formavimo poreikiais: už nepristatytus arklius kavalerijos pulkui, raitelių uniformai (surinkta trečdalis numatytos sumos), dvarams, neturintiems nustatyto valstiečių dūmų skaičiaus, nuo kurio renkamas

\footnotetext{
${ }^{61}$ Dvarų, turinčių 2-15 kiemų, -8 auks., 40 kiemų -10 auks., nuo 40 iki 80 kiemų - 30 auks., nuo 80 iki 250 - 60 auks., nuo 250 iki 480 - 100 auks., nuo 480 iki 1000 - 300 auks., o nuo 1000 kiemu -500 auks. savininkai ir nuomotojai. Bežemiai bajorai -4 auks., valstiečiai činšininkai - 2 auks., lažininkai - 1 auks. Amatininkai meistrai - 4 arba 10 auks., priklausomai nuo kategorijos, o pirkliai - nuo 30 auks. Parapijų klebonai, vikarai - 10 auks. $1812 \mathrm{~m}$. rugpjūčio $12 \mathrm{~d}$. LDK laikinosios vyriausybès komisijos nutarimas dèl rinkimo nuo visų Lietuvos gyventojų mokesčių, pavadintų „,asmenine vienkartine auka“, Lietuvos TSR istorijos šaltiniai, t. 1, p. 400-403.

62 Iwaszkiewicz. J. Litwa w roku 1812, s. 192-193.

${ }^{63}$ Постановление Комиссии Временого Правительсва Великого Княжества Литовского об обложении духовенства благотворительним сбором, Военский К. Min., veik., p. 197-192. ${ }^{64}$ Pugačiauskas V. Napoleonas ir Vilnius: karinio gyvenimo kasdienybės bruožai, p. 54-55.
} 
rekrutas, žydams ir kitiems asmenims, kuriems anksčiau buvo netaikoma rekrutu prievolè, pagalvès - pradiniam rekruto išlaikymui, išimtinai miestiečiams - žandarmerijos ir tautinès gvardijos išlaikymui ${ }^{65}$. Taigi gyventojai, slegiami rekvizicijų naštos, atsidūré sudètingesnèje situacijoje, kadangi derėjo surasti lëšų ne tik iprastiniams, bet ir specialiesiems mokesčiams.

\section{Kariniuose susidūrimuose patirti nuostoliai}

Lietuvos reguliariosios kariuomenès ir atskirų dalinių formavimas, kaip žinome, iki karo nebuvo visiškai baigtas, o joje galejjo tarnauti apie 17000 karių. Nustatyti tikslų Lietuvos kariuomenès karių žuvusių, sužeistų ir paimtų i nelaisvę skaičiu yra sudètinga, kadangi disponuojame negausiais ir nepakankamai tiksliais duomeninis. Didžiulējẻ teritorijoje išmètyti, menkai apginkluoti ir apmokyti Lietuvos pulkai kartu su Didžiosios Armijos daliniais dalyvavo 4 didesniuose susiremimuose. Pirmasis nuo rusų gvardijos nukentejjo lengvosios kavalerijos pulkas, vadovaujamas brigados generolo Jono Kanopkos, kurị spalio 19 d. Slonime sutriuškino rusų generolo P. Čiaplico dalinys. Sprendžiant iš generolo Pranciškaus Koseckio korespondencijos, 70 žuvo arba sbuvo užeista, generolas Kanopka su 13 karininkų ir 253 kariais pateko ị nelaisvę, likusieji sugebejo atsitraukti ${ }^{66}$.

Antrajame mūšyje didesnių nuostoliu patyrè 3 pulkai: pulkininko Stanislavo Čapskio 22-asis péstininku pulkas, ne iki galo sukomplektuotas ir savo gretose turintis apie 1500 karių, 18-asis ulonų pulkas (apie 940 raitelių) ir pulkininko Juozapo Kosakovskio pėsčiujų šaulių pulkas, sudarytas iš dviejų batalionų (634 kariai), dalyvavo mūšyje prie Koidanovo patyrè didelių nuostolių. Tačiau žuvusių, sužeistų ir patekusių į nelaisvę skaičius lieka neaiškus. Trečiasis susidūrimas su užgrūdintais mūšiuose rusų daliniais i̇vyko ties Berezina, kuriame dalyvavo anksčiau paminėti daliniai bei 19-asis ulonų pulkas, taip pat Minsko departamento žandarmerija. Tesužinome, kad šaulių menkos pajègos buvo visiškai sunaikintos, o žandarai neteko 9 karininkų. Apie patirtus nuostolius galima spręsti tik remiantis žiniomis apie pulkų sudèti jiems traukiantis iš Lietuvos: 18-ajame pès-

\footnotetext{
65 Iwaszkiewicz. J. Litwa w roku 1812, s. 164, 178, 196-197; О взыскании с обывателей после 15 сентября за каждого преставленого рекрута по 21 рублю, вместе положених 7 рублей, Акты, издаваемые Виленскою комиссиею для разбора древних актов, т. 37, с. 320.

66 Tyszkiewicz J. Historia 17 pułku ułanów na tłe wojsk Litewskich 1812-1814, Gdynia, 2004, s. 9; Charkiewicz W. Rok 1812 w powiecie Slonimskim, Slonim, 1936, s. 16-17; Dundulis B. Lietuva Napoleono agresijos metais, p. 108.
} 
tininkų pulke tebuvo18 karininkų, 48 puskarininkai ir eiliniai, 18-ajame ulonų - 112, 19-ajame ulonų - apie 100 karių, yra duomenų, kad didesnioji dalis karių išsibėgiojo. Ketvirtasis susidūrimas, pareikalavęs aukų, ìvyko Vilniuje, prie Aušros vartų, gruodžio mèn 9 ir 10 d. Žuvo 63 -iojo jègėrių bataliono karininkai bei Lietuvos totorių eskadronas - pulko vadas pulkininkas Murza Achmatovičius, 10 karininkų ir 80 eilinių ${ }^{67}$. Nederètų pamiršti ir lietuvių, i̇stojusių i Didžiosios Armijos dalinius, pavyzdžiui, 120-asis pėstininkų pulkas ir Ilyrijos pulkas, kurie dislokacijos Vilniuje, o vèliau Minske metu gavo Napoleono leidimą papildyti savo gretas po 500 vietinių rekrutų, tačiau apie surinktų karių skaičių ir galimas netektis neturime kokrečiu duomenų ${ }^{68}$.

Remiantis turimais duomenimis, galime teigti, kad žuvusių ir sužeistų mūšiuose skaičius galejjo svyruoti nuo 1000 iki 2000 kariuc, dar daugiau pateko i nelaisvę. Galima teigti, kad didžioji dauguma karių (iš 17000 karių, ivvairiais skaičiavimais, už Lietuvos ribų pasitraukè nuo 3402 iki 4500 karių) nebenorèdami kariauti už Lietuvos ribų ir apimti panikos tiesiog išsivaikščiojo: kitaip paaiškinti, kodèl daliniuose, kurie nedalyvavo mūšiuose, nebeliko karių, būtų pakankamai keblu. Tokia padètis susikloste 4 péstininku pulkuose: 18 -ajame iš 1650 karių nebeliko pusès, 19-ajame iš beveik 2000 pasiliko tik 22 karininkai ir 17 eiliniu, 20-ajame ir 21-ajame laisvai pasitraukusių buvo mažiau, tačiau taip pat skaičiuojama šimtais. Naugarduke dislokuoto 19 ulonų pulko karių, apimtų panikos dèl rusų dalinių grèsmès, taip pat išsibėgiojo ${ }^{69}$.

Pabaigoje derètų aptarti bendrą žuvusių civilių gyventojų skaičių. Tiesą pasakius, susiduriame su didelėmis problemomis dẻl šaltinių stokos ir ypač dẻl jų nepatikimumo. Istorinèje literatūroje nepagrisstai teigiama, remiantis „Generalinejje lentelèje“" pateiktais duomenimis, kad Vilniaus departamente žuvo ir dingo apie 47774 vyrų, o Gardino departamente - $37699^{70}$. Iš anksčiau aptartos medžiagos paaiškèjo, kad nuostoliai turèjo būti gerokai mažesni. Dera atkreipti

\footnotetext{
${ }^{67}$ Glemža L. Lietuviški kariniai daliniai Prancūzijos kariuomenejje, Karo archyvas, t. XVIII, Vilnius, 2003, p. 154, 156, 165-166; Gembarzewski B. Wojsko polskie Księstwo Warszawskie 1807-1814 r. Warszawa, 1905, t. 1, s. 81; Notice historique sur les armements qui lieu en Lituanie pendant l'occupation franēaise, Военский K, Min., veik, p. 419-422; Dundulis B, Lietuva napoleono agresijos metais, p. 109; Kukiel M. Wojna 1812 roku, t. 2, s. 471.

${ }^{68}$ Dundulis B. Napoléon et la Lituanie en 1812, p. 213, 289

${ }^{69}$ Yra duomenų, kad 19-ojo pėstininkų pulko kariai galutinai išsibėgiojo po susidūrimo su kazokais ties Vilniumi. Kukiel M. Dzieje wojska polskiego w dobie Napoleońskiej 1795-1815, Warszawa, 1920, t. 2, s. 161; Glemža L. Min., veik, p. 154, 165-166. İ šị skaičių neịtraukti nuostoliai, kuriuos patyrè lietuviški kariniai daliniai, pasitraukę už Lietuvos ribų ir dalyvavę 1813-1814 metų karinèse kampanijose.

70 Dundulis B. Lietuva Napoleono agresijos metais, p. 117; Iwaszkiewicz J. Regestracja i indemnizacija strat wojenych na Litwie w roku 1812, s. 140.
} 
dèmesi i keletą esminiu aplinkybių. Pirma, susipažinus su minètos komisijos protokolais paaiškejja, kad liustratoriai skaičiavo ir civilių gyventojų mirtis ne tik 1812 m. antroje pusejje, bet ir 1813 m., t. y. kai mirtingumas Lietuvos Vyriausybei pavaldžiose teritorijose buvo pasiekęs aukštą lygi dẻl po karo išplitusios šiltinès epidemijos. Antra, i ši skaičiu pateko asmenys, prancūzmečiu paimti i rekrutus, mirę natūralia mirtimi bei laikinai pasitraukę iš savo gyvenamujų vietovių. Tokị laisvai traktuojamą rusų liustratorių skaičiavimo metodikos panaudojimą paliudija gausybė faktografinių duomenų $u^{71}$. Taigi remiantis šiuo dokumentu neįmanoma pateikti netgi preliminaraus žuvusių, mirusių ir dingusių be žinios civilių gyventojų skaičiaus.

\section{Baigiamosios pastabos}

1812 m. kare Lietuva patyrẻ nemažų nuostolių dẻl Rusijos kariuomenės rekvizicijų, priešininkų karinių veiksmų, o ypač Didžiosios Armijos savivaliavimo bei didžiulès rekviziciju naštos, užgulusios kiekvieno gyventojo pečius. Karo padariniai, skaičiuojant vien tik aritmetinę materialinę nuostolių išraišką, galima sakyti, stipriai sulètino Lietuvos, po valstybès padalijimo nesuspejusios atsigauti ekonomiškai ir morališkai, plètotę: žemès ūkis, pagrindinis krašto ekonominio potencialo variklis, prarado apie $50 \%$ iki karo turètu pajègumų. Dvarai ir valstiečiai pristigo traukiamosios jëgos, miestai, miesteliai ir kaimai buvo smarkiai nuniokoti, dalis pastatų sudeginta. Nuskurdusiems gyventojams prireikè nemažai laiko vien tiktai savo jègomis atstatyti sugriautus ūkius. Minèti ịvykiai, taip pat civilių gyventojų aukos bei karių žūtys mūšiuose ar mirtys dẻl šiltinès bei kitų ligų turèjo įtakos šalies demografinès situacijos blogèjimui.

Iteikta 2006 m. Lapkričio 21 d.

\footnotetext{
71 Pateikiame kelis klasikinius pavyzdžius: Šiaulių mieste iš 1115 gyventojų tebuvo likę 451, iš kurių potenciali dauguma sugrįžo po karo. Aukštadvaryje iš 119 vyrų ir 80 moterų napoleonmečiu ir pokariniu laikotarpiu, 19 miré nuo šiltinès, 3 pasitraukẻ dèl neaiškių priežasčių, 2 paimti ị rekrutus. Upytės apskrities liustracijos raštai, LVIA, f. 529, ap. 1, 1. 1-2; Lydos apskrities liustracijos raštai. Ten pat, b. 842, 1. 1-3, 5, 6; Naugarduko apskrities liustracijos raštas. Ten pat, b. 845, 1. 3; Volkovysko apskrities liustracijos raštas. Ten pat, b. 2153, 1. 1-2, 5, 20-21; 1812 m. sunaikintų namų ir dingusių gyventojų skaičius. Iš Vilniaus civilinio gubernatoriaus D. N. Bantyš-Kamenskio pranešimo, Lietuvos TSR istorijos šaltiniai, t. 1, p. 404.
} 


\title{
PERTES DE LA LITUANIE PENDANT LA GUERRE DE 1812
}

\author{
Dr. Virgilijus PUGAČIAUSKAS, \\ Académie militaire de la Lituanie, Institut d'histoire
}

Pendant la guerre de 1812 entre la Russie et la France, la Lituanie comme une alliée de la dernière dont les hommes politiques et la société aspiraient à la restauration de la puissance, était engagée dans la zone des actions militaires. Donc, ses habitants ont subi toutes les dificultés de la guerre et des actions militaires. D'abord, dans le territoire de la Lituanie il n'y avait pas de fortes confrontations avec des adversaires, mais au début de la guerre la Lituanie a subi des grands dégâts à cause du comportement inadmissible de la Grande Armée, surtout à cause des maraudeurs dont la fureur a obtenu le caractère général. Le résultat de ces actions c'était la propriété de la population et les constructions publiques brulées et ravagées, les victimes civiles de violence devait atteindre jusqu'à 200 personnes. Deuxième facteur qui exigeait de grandes dépenses matérielles c'était la réquisition des provisions, du fourrage et du transport destinée à la grande armée retirée à la profondeur de Russie. À l'époque française la population lituanienne a effectué 4 grandes réquisitions et plusieurs du caractère différant. La plupart n'était pas complétement effectuée à cause de dépassement du potentiel économique du pays (la construction des équipements défensifs, la traction des bateaux dans la rivière la Neris). Après un fort accroissement des dépenses militaires, la commission provisoire du pouvoir a élargi la base des impots, en introduisant de nouvelles taxes supplémentaires qui devaient être payés par toute la population sans aucune exeption quoique soit leur classe, réligion ou la nationalité. Enfin, à la fin de la guerre le peuple du pays a subit des pertes énormes à cause des confrontations des unités militaires adversaires, des réquisitions forcées et du comportement inadmissible de deux armées.

17000 hommes pouvaient faire le service militaire dans les régiments de cavalérie et d'infanterie des forces armées d'active et dans les autres unités déployées dans le grand territoire. Les hommes mal armés et instruits participaient dans 4 batailles contre les russes et dans les coolisions au bord de Berezina. Le nombre de morts et blessés pouvait être entre 1000 et 2000 hommes, la même quantité était fait prisonniers et ceux qui ne voulaient pas combattre à l'extérieur 
se sont retirés avec des unités de la grande armée.

Les conséquences de la guerre et des dégâts matériels, ont ralenti le dévéloppement de la Lituanie - l'agriculture, le stimulant essentiel du potentiel économique du pays, a perdu environ $50 \%$ de capacité du potentiel économique et aussi a empiré la situation démographique. 